\title{
Characteristics of a gun exchange program, and an assessment of potential benefits
}

\author{
Michael P Romero, Garen J Wintemute, Jon S Vernick
}

\begin{abstract}
Objectives-To describe a gun exchange program and assess potential benefits for participants and host communities. Methods-Mail survey of participants in a Sacramento, California gun exchange program, August 1993; the response rate was $79 \%$. Comparative data were obtained from nationwide polls of gun owners. Results-Most (62\%) respondents were men; $40 \%$ were more than 55 years old; none was less than 25. Concern that children might find and use the gun was the most frequently cited reason for participating ( $46 \%$ of respondents). Of 141 firearms exchanged, $72 \%$ were handguns; $23 \%$ of respondents indicated that the guns they turned in were not in working order. Of respondents who owned a gun at the time of the program (rather than those who owned no guns and turned in a gun owned by someone else), $41 \%$ owned no guns after participating; the prevalence of handgun ownership declined from $79 \%$ to $32 \%$. Those who continued to own guns were as likely as gun owners nationwide to keep a gun loaded in the house (odds ratio (OR) $0.9,95 \%$ confidence interval (CI) 0.4 to 1.7 ) or to carry a gun with them (OR $1.5,95 \%$ CI 0.6 to 3.8 ).

Conclusions-Gun exchange programs may reduce risk for firearm violence among some participants, but a number of factors limit their overall benefits to host communities.
\end{abstract}

(Injury Prevention 1998;4:206-210)

Keywords: firearms; violence; consumer participation; program evaluation

Violence Prevention Research Program, University of California, Davis

M P Romero

G J Wintemute

Center for Gun Policy and Research, School of Hygiene and Public Health, The Johns Hopkins University, Baltimore J S Vernick

Correspondence and reprint requests to: Michael P Romero, Violence Prevention Research Program, 2315 Stockton Blvd, Sacramento, CA 95817, USA (e-mail:

mromero@u.washington.edu).
Rates of firearm related and other violent crime in the US, though dropping since 1992, remain high. ${ }^{12}$ At the same time, approximately $40 \%$ of American households own at least one firearm, and more than half of these own at least one handgun. ${ }^{3}$

Countries such as Australia and the UK have sought to reduce firearm violence by substantially reducing the availability of certain types of firearms. Australia has imposed strict licensing requirements on the possession of semiautomatic firearms; more than 640000 such firearms have been surrendered and destroyed. ${ }^{4}$ In 1998, UK essentially banned the private ownership of handguns. ${ }^{5}$

In the US, where the mandatory populationwide surrender of firearms has little support, voluntary approaches have been adopted. More than 100 gun buy-back or exchange pro- grams were conducted by communities across the country during 1992-96 (unpublished data, authors' Nexis search). These programs have removed thousands of firearms from circulation, ${ }^{6}$ and they enjoy broad public support. ${ }^{7}$ But they have not been shown to lower rates of firearm violence ${ }^{78}$ and have been derided as ineffective, possibly counterproductive "feel-good measures". 6

Such programs continue to be promoted and conducted. Yet little is known about the individuals who participate, what motivates them to do so, or how gun owners who participate in such programs compare with gun owners generally.

Furthermore, changes in participants' risk of firearm violence have largely been ignored. Since few of these programs remove more than $2 \%$ of firearms from circulation in the host community, ${ }^{6}$ it seems appropriate that participant based, not community-wide, outcomes should be evaluated. One such outcome might be a gun exchange program's effect on firearm ownership among participants. Exposure to a firearm, and particularly exposure to a loaded handgun, have been established as risk factors for both homicide ${ }^{910}$ and suicide. ${ }^{10-12}$ The prevalence of these risk factors might be beneficially affected by a gun exchange program.

We conducted a survey of participants in a Sacramento, California gun exchange program. Our objectives were to describe the participants and the guns they exchanged, to compare participating gun owners with gun owners nationwide, and to identify any change in prevalence of risk factors for firearm violence among participants.

\section{Methods}

During the last week of August 1993, the Sacramento Police Department conducted a gun exchange program in which participants received vouchers tickets to games played by the local National Basketball Association franchise. The program was widely promoted in the local media.

One hundred and twenty seven people participated. Police recorded a brief description of the gun; the participant's name, address, and date of birth were recorded if consent was given. No background checks or criminal investigations of participants were conducted. Eleven participants did not permit the police to record identifying information, leaving 116 potential respondents for our study. We designed the questionnaire and conducted the survey following a method proven to be successful in varied populations. ${ }^{13}$ The 
Table 1 Demographic characteristics of all survey respondents, gun owners among respondents, and a comparison group of gun owners from a national public opinion survey; values are number (\%)

\begin{tabular}{|c|c|c|c|}
\hline Characteristic & $\begin{array}{l}\text { All survey } \\
\text { respondents } \\
(n=92)\end{array}$ & $\begin{array}{l}\text { Gun owners } \\
\text { among respondents } \\
(n=74)\end{array}$ & $\begin{array}{l}\text { Gun owner } \\
\text { comparison group }{ }^{*} \\
(n=605)\end{array}$ \\
\hline \multicolumn{4}{|l|}{ Gender } \\
\hline Male & $57(62)$ & $51(69)$ & $454(75)$ \\
\hline Female & $33(36)$ & $22(30)$ & $151(25)$ \\
\hline Unknown & $2(2)$ & $1(1)$ & - \\
\hline \multicolumn{4}{|l|}{ Age (years) } \\
\hline$<35$ & $14(15)$ & $12(16)$ & $230(38)$ \\
\hline $35-54$ & $39(42)$ & $33(45)$ & $169(28)$ \\
\hline $55+$ & $37(40)$ & $28(38)$ & $206(34)$ \\
\hline Unknown & $2(2)$ & $1(1)$ & - \\
\hline \multicolumn{4}{|l|}{ Income } \\
\hline$<\$ 20000$ & $10(11)$ & $9(12)$ & $121(20)$ \\
\hline$\$ 20000-\$ 49000$ & $45(49)$ & $38(51)$ & $278(46)$ \\
\hline$\$ 50000+$ & $30(33)$ & $22(30)$ & $91(15)$ \\
\hline Unknown & $7(8)$ & $5(7)$ & $115(19)$ \\
\hline
\end{tabular}

^1989 Yankelovich Clancy Shulman, national public opinion survey of gun owners.

Table 2 Selected firearm related experiences of gun owners among survey respondents and comparison groups of gun owners from national public opinion surveys, and OR (95\% CI) for respondents having had these experiences

\begin{tabular}{llll}
\hline & $\begin{array}{l}\text { No (\%) of } \\
\text { respondents who } \\
\text { were gun owners } \\
(n=74)\end{array}$ & $\begin{array}{l}\text { No (\%) of gun } \\
\text { owner } \\
\text { comparison } \\
\text { group }\end{array}$ & OR (95\% CI) \\
Characteristic & $41(55)$ & $478(79)^{\star}$ & $0.3(0.2$ to 0.5$)$ \\
\hline Parents had guns in the house & $41(55)$ & $478(79)^{\star}$ & $0.3(0.2$ to 0.5$)$ \\
Formal training with guns & $6(8)$ & $17(8) \dagger$ & $1.0(0.3$ to 2.8$) \ddagger$ \\
Used gun defensively & $18(24)$ & $133(22)^{\star}$ & $1.1(0.7$ to 2.0$)$ \\
Knew someone shot in a crime & $19(26)$ & $248(41)^{\star}$ & $0.5(0.3$ to 0.9$)$ \\
Knew someone shot unintentionally & & 240
\end{tabular}

^1989 Yankelovich Clancy Shulman, national public opinion survey of gun owners $(n=605)$. †May 1991 Gallup Organization, Gallup Poll, national public opinion survey of pistol owners ( $n=210$, subpopulation of 1002 adults). $\ddagger$ Exact test.

survey was conducted from February through April 1994.

The questionnaire contained 50 questions and covered: (1) administration of the program itself, (2) reasons for turning in a gun, (3) experience with guns, (4) the guns exchanged, (5) current gun ownership, (6) storage of guns, and (7) demographics. Of these 50 questions, 19 came from five previously published national public opinion polls of gun owners (Gallup Organization, Gallup Poll, March 1991; Yankelovich Clancy Shulman for Time/CNN, 1989; Gallup Organization, Gallup Poll, May 1991; National Opinion Research Center, General Social Survey, 1991; Gallup Organization, Gallup Poll, November 1991). Questions taken from these polls were obtained by a computerized search of public opinion survey data from the Roper Center for Public Opinion Research at the University of Connecticut. These questions allowed us to compare gun owners who responded to our survey with gun owners nationwide. (Available resources did not permit a separate community-wide survey of gun ownership and usage practices in our study area.)

Participant identifying information and descriptions of the weapons exchanged, including type and caliber, were obtained from police records filled out at the time of the program. Weapon types included handguns (pistols, revolvers), long guns (rifles, shotguns), and airguns. Handguns were classified as small caliber $(.22, .25, .32)$, medium caliber $(.38, .380,9$ $\mathrm{mm})$, or large caliber $(.357, .45)$. An identification number linked questionnaires with the police department's records of the exchange program.

The odds ratios (ORs) were calculated using confidence interval (CI) analysis software, and exact tests were calculated using Epi-Info software, with $\propto=0.05$ chosen as the level of statistical significance.

\section{Results}

The response rate was $79 \%(92 / 116)$. Most respondents $(62 \%)$ were male. Forty per cent were more than 55 years of age, $15 \%$ were less than 35 , and none was less than 25 . At the time of the program, $25 \%$ of respondents had a child under 14 years of age living with them; $13 \%$ had a young adult 15 to 24 years of age at home.

Seventy four respondents $(80 \%)$ owned guns at the time of the program; the remaining 18 $(20 \%)$ turned in guns that they had found or that were owned by others. Compared with gun owners nationwide, gun owners among our respondents were older and of higher socioeconomic status (table 1 ).

Respondent gun owners gave evidence of both similarities and differences with gun owners nationwide in their experience with guns (table 2). They were less likely to have grown up with guns or to have had any formal training with guns, but were equally likely to have used a gun defensively or to have known someone who had been shot in a violent crime. In addition, $32 \%$ of respondent gun owners knew someone who had used a gun to commit or attempt suicide; no comparison data were available.

Almost half the respondents $(46 \%)$ cited concern that children might get and use the gun as an "important" reason for their participation in the program (fig 1). Fewer than $15 \%$, however, reported a previous bad experience with a gun or concern for a possible shooting in their home as important. Comments illustrating the range of participants' reasons for exchanging guns are presented in table 3.

Of 141 firearms exchanged, 40 (28\%) were long guns and 101 (72\%) were handguns, including 66 revolvers and 35 pistols. Of the handguns, $63 \%$ were small caliber, $26 \%$ were medium caliber, $8 \%$ were large caliber, and 3\% were of unknown caliber. Participants also exchanged 10 airguns, three Tasers (hand held devices that deliver electric shocks), and numerous boxes of ammunition. Most participants $(87 \%)$ turned in one firearm, $8 \%$ turned in two or more, and 5\% turned in only airguns. Almost one fourth of the respondents (23\%) indicated the gun was not in working order, and another $24 \%$ were not sure. Most respondents $(85 \%)$ had the gun in their household for more than one year.

Of respondents who were gun owners at the time of the program, $29(41 \%)$ no longer owned any guns at the time of our survey 6-8 months later. The percentage of responding gun owners with more than one gun declined from $62 \%$ to $35 \%$. The prevalence of handgun ownership among responding gun owners was reduced from $79 \%$ to $32 \%$. 


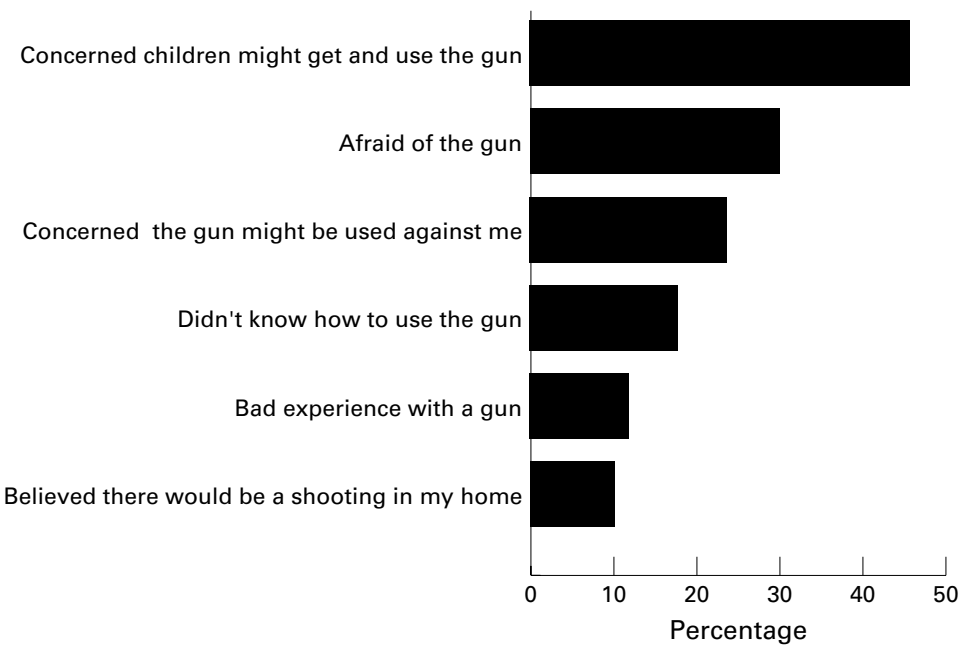

Figure 1 Percentage of respondents indicating that each of six possible reasons for turning in a gun was "important" in their decision to participate in the exchange program.

Forty three respondents retained at least one gun in their household after participating in the program. Of these, 23 (53\%) still kept a handgun and $30(70 \%)$ still kept a long gun (table 4). These continuing gun owners were just as likely as gun owners nationwide to keep a gun loaded, to store some or all of their guns unlocked, and to carry a gun on their person or in their car or truck. Continuing gun owners, however, were less likely than gun owners nationwide (OR $0.6,95 \% \mathrm{CI}, 0.3$ to 1.0 ) to retain more than one gun in their household.

\section{Discussion}

Exposure to a gun - particularly a handgunhas repeatedly been associated with a substantial increase in risk of fatal firearm violence. ${ }^{9-12}$ Our findings suggest that reduction in risk of firearm violence occurs for participants in gun exchange programs and members of their households, in that the prevalence of both gun ownership and handgun ownership have been reduced. Forty one per cent of gun owners no longer had any guns after the program, and the prevalence of handgun ownership declined by well over one half.

However, the community-wide benefit of such programs is probably less than such findings might suggest, for several reasons. First, while many participants no longer had any guns after the program, those who still had guns used them as other gun owners do, often keeping a gun loaded and unlocked, or concealed on their person or in their vehicle. These behaviors may be associated with a higher risk of firearm injury.

Second, as in other such programs, ${ }^{78}$ participants in Sacramento's gun exchange program were older than other gun owners. No more than two of all 127 participants in the

Table 3 Selected comments on reasons for participating in gun exchange program

\begin{tabular}{|c|c|c|c|}
\hline $\begin{array}{l}\text { Demographic } \\
\text { characteristics }\end{array}$ & $\begin{array}{l}\text { Children }<14 \\
\text { at home? }\end{array}$ & $\begin{array}{l}\text { Continuing } \\
\text { gun owner? }\end{array}$ & Comments \\
\hline WF, age 45-54 & Resident & No & $\begin{array}{l}\text { My mother died, leaving me her home and everything in it. } \\
\text { Actually, the first action I performed, even before arranging } \\
\text { the funeral, I think, was to find and turn in all the guns in } \\
\text { the house. (Both my parents were avid hunters and firmly } \\
\text { believed in gun ownership. I'm completely opposed to both } \\
\text { hunting and guns-especially with a young child in the } \\
\text { house.) }\end{array}$ \\
\hline WM, age $45-54$ & Frequent visitors & Handgun & $\begin{array}{l}\text { We obtained the gun from our son who was living with us at } \\
\text { the time. He was having problems with gang members in } \\
\text { our neighborhood. The gun was never completely } \\
\text { assembled when we confiscated it from him. He got the gun } \\
\text { from a friend at school for protection. He had turned it in } \\
\text { to a juvenile counselor who would not take it. }\end{array}$ \\
\hline WM, age $55+$ & Frequent visitors & No & $\begin{array}{l}\text { I have four beautiful grandsons, } 11-8-6-5 \text {, who are now living } \\
\text { in Montana-one year. Before they left one or all were } \\
\text { staying with us. I kept the gun in a shoe box on the top shelf } \\
\text { of a closet. One day my beloved } 8 \text { year old said, "Papa, I bet } \\
\text { your gun is in that heavy box in your office closet"-that } \\
\text { did it. I love him more than life itself so I took the gun and } \\
\text { ammo down the street two blocks to my brother in law, an } \\
\text { officer on Sac[ramen] to Police Department- to turn in for } \\
\text { me-nothing in the world is worth an accident involving my } \\
\text { little ones. }\end{array}$ \\
\hline WF, age $55+$ & No & Shotgun & $\begin{array}{l}\text { The handgun which I turned in was taken from my home in } \\
\text { Los Angeles during a burglary in } 1971 \text {. The gun was new } \\
\text { and had never been used. It was recovered by the police } \\
\text { almost a year later and returned to me. The gun had been } \\
\text { in and out of a waistband or pocket so often that the bluing } \\
\text { had been rubbed off. The handle was cracked and chipped } \\
\text { and the shell ejection rod was missing. In short, it had seen } \\
\text { a lot of use. I have always felt extremely uncomfortable } \\
\text { about the gun having been used for criminal purposes. My } \\
\text { reason for turning in the handgun was to prevent this from } \\
\text { happening again. }\end{array}$ \\
\hline HM, age $55+$ & Daily visitors & No & $\begin{array}{l}\text { Guns for private citizens should be illegal to possess. If people } \\
\text { need a gun for hunting they could rent one. Rental of guns } \\
\text { would then be strictly regulated. }\end{array}$ \\
\hline WM, age $45-54$ & No & Unknown & $\begin{array}{l}\text { This handgun was old and not in working condition and } \\
\text { would have cost me more to repair than it was worth. It was } \\
\text { simply a way to dispose of it safely and to get limited value } \\
\text { for it. I support the } 2 \text { nd Amendment to the Constitution! I } \\
\text { support voluntary surrender of unwanted weapons by those } \\
\text { who choose to do so. }\end{array}$ \\
\hline
\end{tabular}


Table 4 Gun ownership and use characteristics of continuing gun owners among survey respondents and comparison groups of gun owners from national public opinion surveys, and OR $(95 \%$ CI) that continuing gun owners would exhibit these characteristics

\begin{tabular}{llll}
\hline & $\begin{array}{l}\text { No (\%) of } \\
\text { continuing gun } \\
\text { owners }\end{array}$ & $\begin{array}{l}\text { No (\%) of gun } \\
\text { owner comparison } \\
\text { group }\end{array}$ & OR (95\% CI) \\
\hline 1 Gun & $17(40)^{\star}$ & $102(22) \dagger$ & $2.3(1.2$ to 4.5$)$ \\
$>1$ Gun & $25(58)^{\star}$ & $334(72) \dagger$ & $0.6(0.3$ to 1.0$)$ \\
Handgun & $23(53)^{\star}$ & $226(47) \ddagger$ & $1.3(0.7$ to 2.4$)$ \\
Gun loaded in house & $12(28)^{\star}$ & $188(31) \S$ & $0.9(0.4$ to 1.7$)$ \\
Gun not locked up & $25(58)^{\star}$ & $321(53) \S$ & $1.2(0.6$ to 2.3$)$ \\
Carry handgun on person & $7(30) \|$ & $48(23) \uparrow$ & $1.5(0.6$ to 3.8$)$ \\
Carry handgun in car or truck & $10(43) \|$ & $82(39) \uparrow$ & $1.2(0.5$ to 2.9$)$ \\
\hline
\end{tabular}

${ }^{\star}$ Continuing gun owners ( $n=43 ; 1$ unknown for number of guns).

†March 1991 Gallup Organization, Gallup Poll, national public opinion survey of gun owners ( $n=465$, subpopulation of 1010 adults).

$\ddagger$ May 1991 Gallup Organization, Gallup Poll, national public opinion survey of gun owners ( $\mathrm{n}=481$, subpopulation of adults).

$\$ 1989$ Yankelovich Clancy Shulman, national public opinion survey of gun owners $(n=605)$.

$\|$ Continuing handgun owners $(n=23)$.

$\uparrow$ May 1991 Gallup Organization, Gallup Poll, national public opinion survey of pistol owners $(\mathrm{n}=210$, subpopulation of 1002 adults).

program were estimated to be less than 25years of age; neither provided identifier data and both were necessarily excluded from our survey (personal communication, A Kozuma, Sacramento Police Department). Females made up a higher percentage of participants than of the general population of gun owners.

Participants in these programs may therefore be at lower risk of firearm violence-or firearm homicide, at least - than are gun owners generally, even before exchanging any firearms. We note, however, that rates of firearm suicide are highest among older males. ${ }^{15}$ It may be that gun exchange programs have a greater potential to lower rates of firearm suicide than of firearm homicide. This remains a matter for further investigation; the one study to address this question found no such effect, but the number of events both before and after the program was too small for any conclusions to be drawn. ${ }^{7}$

In addition, a quarter of the guns exchanged in this program were reported not to be in working order and thus posed little potential for violence in the first place. This is a greater proportion than in the one other site from which data are available; in Seattle, $83 \%$ of firearms were reported to be operational and the status of another $14 \%$ was unknown. ${ }^{7}$

Finally, guns returned during exchange programs may not resemble the guns most frequently used in crime. For example, semiautomatic pistols made up $17 \%$ of buy-back guns in the city of Boston in 1993-94, but 32\% of firearms confiscated by that city's police department from persons age 30 and older, and $52 \%$ of firearms confiscated from persons age 21 and younger, in that city during 1991-95. Long guns (rifles and shotguns) made up $42 \%$ of buy-back guns and a similar $39 \%$ of firearms confiscated by police from persons age 30 and older, but only $18 \%$ of firearms confiscated from persons age 21 and younger. ${ }^{16}$

Data from a separate study of firearms confiscated by police in Sacramento in 1995 suggest that similar differences exist in our study area. ${ }^{17}$ Long guns made up $28 \%$ of the exchanged guns in the present study but $18 \%$ of confiscated firearms. Semiautomatic pistols made up only $35 \%$ of the handguns in the exchange program and $57 \%$ of the handguns confiscated by police in 1995 .

There are several limitations to this study. We did not have any information on the 11 program participants to whom questionnaires could not be sent or on the 24 non-respondents to the questionnaire. Since this was a relatively small survey of one city's gun exchange program, it may not be appropriate to generalize our results to other such programs, although results for other sites are similar. ${ }^{7816}$ Due to resource limitations we were not able to gather data from the general population of gun owners in Sacramento for comparison purposes, and it is possible that the observed differences between our respondents and gun owners nationwide are related to factors such as regional variations in gun usage rather than participation in the gun exchange program.

What are the implications of these findings for persons conducting, or considering, gun exchange programs? Concern that children might gain access to a gun was the most frequently cited reason for participating. Persons planning future programs might want to emphasize their potential benefits for children and young adults.

At the same time, the dearth of young adults among program participants poses a major challenge. The same problem has been noted elsewhere. ${ }^{78}$ Our data cannot determine if this was due to a perceived need by young people to keep a gun, the type of incentive offered, the involvement of the police department, or ineffective advertising. For gun exchange programs to be optimally effective, future efforts must work to include high risk youth. As rates of violent crime among young people decrease, the perceived need to own a firearm for protection may decrease as well, making this task easier.

Lastly, our respondents who still owned guns often kept them loaded and easily accessible. Information on the risks that may be associated with those behaviors should be provided to program participants.

Communities may also wish to consider other measures to prevent firearm violence that rely at least in part on reducing the number of firearms available for criminal use. In a controlled experiment in Kansas City, law enforcement efforts focused on confiscating illegal firearms resulted in a substantial reduction in firearm crime. ${ }^{18}$ In Boston, tracing of all confiscated firearms has increasingly made it possible to disrupt the activities of firearms traffickers, which has contributed to a substantial decrease in homicide rates. ${ }^{19}$ In St Louis, a voluntary search and seizure program has resulted in the confiscation of several hundred firearms per year; an outcome evaluation is pending. ${ }^{20}$ As these and other programs are replicated and evaluated, the relative cost effectiveness of gun exchange programs will be better understood.

The authors would like to thank Sacramento Police Chief Arturo Venegas and the Sacramento Police Department Property Management Division, especially Ashley Kozuma and Christopher Hadley, for their support and assistance throughout his project.

This project was supported in part by a grant from the California Wellness Foundation. 
1 Ringel C. Criminal victimization 1996: changes in 1995-96 with trends 1993-96. Washington, DC: Bureau of Justice Statistics, 1997. (Publication No NCJ-165812.)

2 Uniform Crime Reports Preliminary Release January through June, 1997. Washington, DC: Federal Bureau of Investigation, 1997. Available at http://www.fbi.gov/ pressrel/ucrnov.htm.

3 National Opinion Research Center. General social surveys, 1972-1994: cumulative codebook. Chicago: University of Chicago, National Data Program for the Social Sciences, 1994.

4 Office of the Attorney General and Minister of Justice. The Australian firearms buyback. Available at http:// 203.2.143.13/intromain.htm

5 Total ban on handguns comes into force today. Home Office press release 032/98, 26 January 1998. Available at press release 032/98, 26 January 1998. Available

6 Kleck G. Gun buy-back programs: nothing succeeds like

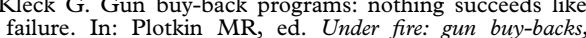
failure. In: Plotkin MR, ed. Under fire: gun buy-backs,
exchanges, and amnesty programs. Washington, DC: Police exchanges, and amnesty programs. Washing

7 Callahan CM, Rivara FP, Koepsell TD. Money for guns: Callahan CM, Rivara FP, Koepsell TD. Money for guns:
evaluation of the Seattle gun buy-back program. Public

8 Rosenfeld R. Gun buy-backs: crime control or community mobilization? In: Plotkin MR, ed. Under fire: gun buy-backs, exchanges, and amnesty programs. Washington, DC: Police Executive Research Forum, 1996: 1-28.

9 Kellermann AL, Rivara FP, Rushforth NB, et al. Gun ownership as a risk factor for homicide in the home. $N$ Engl $f$ Med 1993;329:1084-91.

10 Cummings P, Koepsell TD, Grossman DC, et al. The association between the purchase of a handgun and homicide or suicide. Am $\mathcal{F}$ Public Health 1997;87:974-8.
11 Brent DA, Perper JA, Allman CJ, et al. The presence and accessibility of firearms in the homes of adolescent accessibility of firearms in the
suicides. $\mathcal{F A M A} 1991 ; \mathbf{2 6 6}: 2989-95$.

12 Kellermann AL, Rivara FP, Somes G, et al. Suicide in the home in relation to gun ownership. $N$ Engl $f$ Med 1992;327:467-72.

13 Dillman DA. Mail and telephone surveys. New York, NY: John Wiley, 1978.

14 Dillman DA. Mail and other self-administered questionnaires. In: Rossi DH, Wright JD, Anderson AM, eds. Handbook of survey research. New York, NY: Academic Press, 1983: 359-77.

15 Anderson RN, Kochanek KD, Murphy SL. Report of final mortality statistics, 1995. Monthly Vital Statistics Report 1995;45(11 suppl 2), 1997:1-80.

16 Kennedy D, Piehl A, Braga A. Gun buy-backs: where do we stand and where do we go? In: Plotkin MR, ed. Under fire: gun buy-backs, exchanges, and amnesty programs. Washington, DC: Police Executive Research Forum, 1996: 141-74.

17 Robinson-Haynes E, Wintemute G. Gun confiscations: a case study of the city of Sacramento in 1995. Sacramento, CA: Violence Prevention Research Program, 1997.

18 Sherman LW, Shaw JW, Rogan DP. The Kansas City gun experiment. Washington, DC: National Institute of Justice, 1995. (Publication No NCJ-150855.)

19 Kennedy DM, Piehl AM, Braga AA. Youth violence in Boston: gun markets, serious youth offenders, and a use-reduction strategy. Law and Contemporary Problems 1996;59:147-96.

20 Rosenfeld R, Decker SH. Consent to search and seize: evaluating an innovative youth firearm suppression program. Law and Contemporary Problems 1996;59:197-220.

\section{It could only happen in Africa.....}

A woman was killed and her husband critically injured when they drove into a kudu (a large buck) on the N1 highway near Naboomspruit on Friday, 27 March. A police spokesman said, "It appears that after hitting the kudu, the man lost control of the car and overturned several times. The kudu seems to have survived because it fled".

A 13 year old Congo boy soldier who shot and killed a Red Cross volunteer in Kinshasa after a dispute on a soccer pitch has been speedily condemned to death by a military tribunal.

and finally.......

A provincial minister of transport had a cow slaughtered next to the swimming pool at his home in honour of his eldest son who was killed in a road accident. Minister S'bu Ndebele was marking, under traditional Zulu custom, the passing of his 24 year old son Nhlakanipho four years after he died. But the slaughter was also in response to public demands to Ndebele's department to hold traditional ceremonies around the province to "settle" the spirits of road accident victims believed to have been stirred up by a recent road safety campaign.

Ndebele said the Siyabakhumbula (We Remember Them) campaign last August had unleashed a flood of pent-up grief. Some bereaved people felt the souls of their loved ones had been disturbed. The campaign was aimed at fostering road safety by remembering accident victims. Under Zulu law, restless spirits can be brought back home only by their families. Every family has to perform its own ceremony, so "S'bu decided to show the way and kill a cow in remembrance of his son", a spokesman said. Ndebele said that the slaughter was "a celebration of life, and, hopefully signifies the end of mourning for me". 